\title{
Work of family health strategy nurses in oncology care
}

\author{
Atuação dos enfermeiros da estratégia saúde da família na atenção oncológica \\ Actuación de los enfermeros de la estrategia salud de la familia en la atención oncológica
}

Geize Rocha Macedo de Souza ${ }^{1}$ Luiza Helena de Oliveira Cazola ${ }^{1}$ Sandra Maria do Valle Leone de Oliveira ${ }^{1}$

1. Universidade Federal de Mato Grosso do Sul. Campo Grande, MS, Brazil.
Corresponding author:

Geize Rocha Macedo de Souza.

E-mail: geize01@yahoo.com.br

Submitted on $01 / 12 / 2017$.

Accepted on 06/26/2017.

DOI: 10.1590/2177-9465-EAN-2016-0380

\section{Abstract}

Objective: To identify the qualification of and to know the work of Family Health Strategy nurses in oncology care. Methods: A cross-sectional, descriptive study, using a quantitative approach, was conducted with 77 nurses working in the Family Health Strategy units of Campo Grande, state of Mato Grosso do Sul. Primary data were collected in structured interviews, using a form with closed-ended questions. Results: Professional training in oncology care is less frequent, reflecting a high lack of knowledge regarding the National Policy on Oncology Care. It was evidenced that $95 \%$ of the professionals assisted oncology patients, with home visits and nursing appointments being the most prevalent methods. Regarding the National Policy on Oncology Care, 96\% of the nurses declared that they did not know about it. Conclusion: There was evidence of weakness in the care provided by the nurses to oncology patients and the need for investment in continuing education for professional nurses regarding oncology care.

Keywords: Primary Health Care; Family Health Strategy; Oncology Nursing; Nursing care.

\section{Resumo}

Objetivo: Identificar a qualificação e conhecer a atuação dos enfermeiros da Estratégia Saúde da Família na atenção oncológica. Métodos: Estudo transversal de abordagem quantitativa, constituído de 77 enfermeiros inseridos em unidades de Estratégia Saúde da Família de Campo Grande, Mato Grosso do Sul. A coleta de dados primários foi realizada por meio de entrevista, utilizando-se um formulário com questões fechadas. Resultados: A capacitação, em atenção oncológica, é pouco frequente, refletindo o elevado desconhecimento da Política Nacional de Atenção Oncológica. Verificou-se que 95\% dos profissionais realizavam atendimentos aos pacientes oncológicos, sendo a visita domiciliar e a consulta de enfermagem as mais prevalentes. Sobre a Política Nacional de Atenção Oncológica, 96\% dos enfermeiros declararam não a conhecer. Conclusão: Evidenciou-se despreparo dos enfermeiros para assistirem os pacientes portadores de câncer e a necessidade explícita de educação permanente.

Palavras-chave: Atenção Primária à Saúde; Estratégia Saúde da Família; Enfermagem Oncológica; Cuidados de Enfermagem.

\section{Resumen}

Objetivo: Identificar la calificación y conocer la actuación de los enfermeros de la Estrategia Salud de la Familia en atención oncológica. Métodos: Estudio transversal, de abordaje cuantitativo, integrado por 77 enfermeros actuantes en unidades de Estrategia Salud de la Familia de Campo Grande, Mato Grosso do Sul. Datos primarios recolectados mediante entrevista, utilizándose cuestionario con preguntas cerradas. Resultados: La capacitación en atención oncológica es poco frecuente, reflejando el elevado desconocimiento de la Política Nacional de Atención Oncológica. Se verificó que 95\% de los profesionales realizaban atenciones a pacientes oncológicos, prevaleciendo la visita domiciliaria y la consulta de enfermería. Sobre la Política Nacional de Atención Oncológica, 96\% de los enfermeros declaró desconocerla. Conclusión: Se evidenció falta de preparación de los enfermeros para atender a pacientes con cáncer, y la necesidad explícita de educación continua.

Palabras clave: Atención Primaria de Salud; Estrategia de Salud Familiar; Enfermería Oncológica; Atención de Enfermería. 


\section{INTRODUCTION}

The World Health Organization (WHO) estimates that by the year 2030, there will be 27 million cases of cancer, with 17 million deaths, and 75 million people annually living with cancer. ${ }^{1}$ In Brazil, the Brazilian Cancer Institute (INCA) estimated approximately 600 thousand new cases of cancer for the biennium 2016-2017.2

In 2005, the Brazilian Ministry of Health $(\mathrm{MH})$ created the Brazilian National Policy on Oncology Care (PNAO, as per its acronym in Portuguese), which determined that cancer patients should receive care that includes the different levels of care, i.e., medium- and high-complexity, primary and specialized care, with actions focused on the individual and the community, on health promotion and cancer prevention, as well as on timely diagnosis and support for tumor therapy and palliative care. ${ }^{3}$

Basic care $(A B)$, a structuring scenario for the development of several actions in the control of neoplasms, is the user's gateway into health services, being characterized as a local privileged place for promotion and prevention actions. ${ }^{4}$ The Family Health Strategy (FHS) should work focusing on family care, the development of bonds, care longitudinality and comprehensiveness, and on the action of population health determinants. ${ }^{5}$

The work performed by FHS nurses involves monitoring the population's health conditions as the essence of nursing care, either individually or collectively, monitoring health problems, and intervening in pathological issues. ${ }^{6}$

Nurses who are members of a FHS team have a position of relevance because they play a proactive role in their activities and stand out as the most prepared and available professionals to support and guide patients and their families in the process of illness, treatment and rehabilitation. ${ }^{7}$

Health professionals, especially nursing professionals, should include, in their daily activities, home care for cancer patients and their families, and work to support these families, to establish bonds, to identify the patients' distressing thoughts of having their wishes met, to be reconciled with him/herself and with others, as well as to support families in the process of death, in a caring and humane manner. ${ }^{8}$

It is worth mentioning that the nurse's role in hospital oncology care is widely discussed, but the literature has not highlighted actions of promotion and prevention, extra-hospital care, and/or palliative care present in basic care.

In view of this issue, the present study aimed to know the work of FHS nurses in oncology care, because the care given to these patients and relatives is challenging, due to their illness singularities and the different types of cancer that the professional identifies in the workplace.

\section{METHODS}

This is a descriptive, cross-sectional study, using a quantitative approach, developed at family health units in the city of Campo Grande, capital of the state of Mato Grosso do Sul.

The population was made up of 99 nurses who worked in the 39 basic family health units, three of them rural units. Teams that did not have nurses were excluded. Thus, the researchers excluded nine teams that, at the time of data collection, did not have a nursing professional; nine nurses who were on vacation or on medical leave; and four who did not accept to participate. At the end of selection, the sample comprised 77 nurses from 37 units, who were invited to participate in the study and who, after accepting it, signed a free and informed consent form.

Primary data collection took place from October to December 2015 in the health units and according to the nurses' availability.

Data were collected using a form containing 25 closedended questions, which addressed the following variables: nurses' sociodemographic and professional characterization: gender, age group, employment relationship, length of service in the FHS, and in the assigned area, type of employment relationship, specializations and skills carried out regarding oncology care; regarding oncology care: cancer patients in their area, and activities with patients and their families, comprehension of the PNAO, facilitating and hindering factors in assisting patients, and skills mentioned as necessary by professionals. The form was validated after a pre-test applied to 10 health professionals, namely a nurse with specialization in oncology, one with experience in oncology patient care, and eight who had already worked in the Family Health Strategy.

Interviews took place at a time previously scheduled by the nurses, individually, performed by the researcher, with average length of 45 minutes.

A descriptive analysis of the data organized in Microsoft Office Excel ${ }^{\circledR}$ spreadsheet was performed, with the questions being grouped according to similar answers, and presented in tables.

The study was approved by the Research Ethics Committee of the Federal University of Mato Grosso do Sul, under report no. 1.249.953.

\section{RESULTS}

In the analysis of the sociodemographic and professional characteristics of the FHS nurses, the study found a predominance of women (91\%), in the age group of 31 to 40 years (54\%), with a permanent employment contract (77\%), and time spent in the FHS and in the assigned area of 24 to 72 months, corresponding to $40 \%$ and $46 \%$, respectively. 
Regarding specialization, $77 \%$ stated that they had one and, among these, $58 \%$ of specializations related to the area of public health or family health. More than half $(65 \%)$ said that they did not have specific oncology health training.

As it can be identified in Table 1, most nurses had oncology patients in their assigned areas, and followed them up mostly through home visits and nursing appointments.

Most respondents reported having knowledge about palliative care, but more than half said they did not employ it because they considered it unnecessary. Regarding chemotherapy and radiotherapy, there was a prevalence in the non-implementation of guidelines oriented to the topic and, when these occurred, it was mainly directed to education about food intake.

Table 2 shows that most nurses were unaware of the PNAO, and that few had a good understanding of oncology care. Regarding the difficulties in assisting oncology patients, less than half reported having them, with the lack of training in oncology being the predominant reason. As for the facilitating factors, among those who reported recognizing them, the guidelines with no emotional appeal were the most reported.

Table 1. Profile of care and activities developed by primary health care nurses in oncology care in the city of Campo Grande, state of Mato Grosso do Sul.

\begin{tabular}{|c|c|c|c|}
\hline Variables & n & $\mathbf{N}$ & $\%$ \\
\hline Cancer patients in the assigned area & 77 & & \\
\hline Yes & & 60 & 78 \\
\hline No & & 17 & 22 \\
\hline Cancer patient care/follow-up & 60 & & \\
\hline Yes & & 57 & 95 \\
\hline No & & 3 & 5 \\
\hline Activities performed with cancer patients ${ }^{(1)}$ & 57 & & \\
\hline Home visit & & 52 & 91 \\
\hline Nursing appointment & & 31 & 54 \\
\hline Technical procedures & & 29 & 51 \\
\hline Discussion in the team meeting & & 24 & 42 \\
\hline Assistance to cancer patients' family members & 60 & & \\
\hline Yes & & 32 & 53 \\
\hline No & & 28 & 47 \\
\hline Activities performed with cancer patients' family members ${ }^{(1)}$ & 32 & & \\
\hline Guidance about care for cancer patients & & 19 & 59 \\
\hline Guidelines about the caregiver's health & & 18 & 56 \\
\hline Psychological support & & 11 & 34 \\
\hline Cancer patients' rights & & 1 & 3 \\
\hline Others & & 3 & 9 \\
\hline Has knowledge on palliative care & 77 & & \\
\hline Yes & & 66 & 86 \\
\hline No & & 11 & 14 \\
\hline Performs palliative care & 66 & & \\
\hline Yes & & 31 & 47 \\
\hline No & & 35 & 53 \\
\hline
\end{tabular}




\section{Continued Table 1.}

\begin{tabular}{|c|c|c|c|}
\hline Variables & n & $\mathbf{N}$ & $\%$ \\
\hline Palliative care performed ${ }^{(1)}$ & 31 & & \\
\hline $\begin{array}{l}\text { General guidance on care regarding food, hygiene, comfort, ulcer } \\
\text { prevention, and alcohol and smoking avoidance }\end{array}$ & & 28 & 90 \\
\hline Pain reduction & & 12 & 39 \\
\hline Medical care and control of tests & & 2 & 6 \\
\hline Does not perform palliative care ${ }^{(1)}$ & 35 & & \\
\hline There is no need & & 20 & 57 \\
\hline Does not have cancer patients & & 10 & 29 \\
\hline Not prepared to care for this kind of patient & & 5 & 14 \\
\hline There is no demand by the patient & & 3 & 9 \\
\hline There is no demand by the team & & 2 & 6 \\
\hline Work overload & & 1 & 3 \\
\hline Offers guidance regarding chemotherapy and radiotherapy & 77 & & \\
\hline Yes & & 30 & 39 \\
\hline No & & 47 & 61 \\
\hline Guidelines about chemotherapy and radiotherapy ${ }^{(1)}$ & 30 & & \\
\hline Nutrition care & & 26 & 87 \\
\hline Side effects & & 16 & 53 \\
\hline Skin care & & 13 & 43 \\
\hline Treatment frequency & & 10 & 33 \\
\hline Fluid intake & & 3 & 10 \\
\hline Care with physical effort & & 2 & 7 \\
\hline Hygiene care & & 1 & 3 \\
\hline Vaccines & & 1 & 3 \\
\hline
\end{tabular}

(1) More than one alternative could be chosen.

Regarding courses and training, almost all nurses stated that they had an interest in acquiring new knowledge, mainly on PNAO and palliative care.

\section{DISCUSSION}

In this study, there was a predominance of female nurses, similar to the findings of another research that showed the participation of women in a higher proportion in nursing, since this job is associated with female work. ${ }^{9}$ Age ranged from 24 to 62 years, with a predominance of the age group from 31 to 40 years old, differently from that found in a study carried out in a city in the south of Brazil, which identified younger professionals. $^{6}$

Stable employment relationships are a favorable condition that allows the consolidation of primary health care guidelines, ${ }^{10}$ which can be considered as a positive result for this study, since most nurses have permanent employment contracts. Length of work in the FHS and in the same assigned area ranged from
2 to 6 years; in other studies, the mean time in the same area was 3 years. ${ }^{6,10}$

Most nurses had a specialization, and more than half related to public health and/or family health; these results were similar to those found in another research where only $62.5 \%$ of the professionals were trained in these areas. ${ }^{10}$

The lack of professionals trained in oncology care may indicate weaknesses in the development of their activities, since $65 \%$ of nurses do not have it. This fact evidences a need for interventions, since the PNAO recommends the qualification of health professionals at all levels of care. ${ }^{3}$

The reality of patients undergoing oncology treatment is increasingly frequent in the community; thus, nursing care requires from the health professional, in addition to technical-scientific knowledge, affectivity, communication, sincerity and empathy, which are constructive elements of care. ${ }^{11}$ Nurses should be prepared to provide quality care, because most of them have declared the presence of cancer patients in their areas, and that they follow them up. 
Table 2. Knowledge, and facilitating and hindering aspects for primary health care nurses working in oncology care, in the city of Campo Grande, state of Mato Grosso do Sul.

\begin{tabular}{|c|c|c|c|}
\hline Variables & $\mathbf{n}$ & $\mathbf{N}$ & $\%$ \\
\hline Knows PNAO & 77 & & \\
\hline Yes & & 3 & 4 \\
\hline No & & 74 & 96 \\
\hline Knowledge about oncology care & 77 & & \\
\hline Cancer patient care & & 53 & 69 \\
\hline Cancer prevention and diagnosis & & 25 & 32 \\
\hline $\begin{array}{l}\text { Care actions including promotion, prevention, diagnosis, treatment, rehabilitation, } \\
\text { and palliative care }\end{array}$ & & 10 & 13 \\
\hline Guidelines regarding the disease & & 9 & 12 \\
\hline Collection of preventive tests, and monitoring of those that show alterations & & 2 & 3 \\
\hline Facilitating and hindering factors in oncology patient care & 77 & & \\
\hline Hindering & & 35 & 45 \\
\hline Facilitating & & 23 & 30 \\
\hline Did not answer & & 19 & 25 \\
\hline Hindering aspects ${ }^{(1)}$ & 35 & & \\
\hline Lack of knowledge on oncology & & 23 & 66 \\
\hline Lack of knowledge on the disease and treatment & & 16 & 46 \\
\hline Work overload & & 12 & 34 \\
\hline Lack of materials and resources & & 7 & 20 \\
\hline Patient and family members do not accept the disease & & 5 & 14 \\
\hline Facilitating aspects ${ }^{(1)}$ & 23 & & \\
\hline Guidelines with no emotional appeal & & 21 & 91 \\
\hline Performance of technical procedures & & 4 & 17 \\
\hline Professional experience & & 2 & 9 \\
\hline Need for courses/trainings & 77 & & \\
\hline Yes & & 74 & 96 \\
\hline No & & 3 & 4 \\
\hline Oncology care themes ${ }^{(1)}$ & 74 & & \\
\hline PNAO & & 57 & 77 \\
\hline Palliative care & & 55 & 74 \\
\hline Care for family members & & 50 & 68 \\
\hline Treatments & & 43 & 58 \\
\hline Promotion, prevention & & 39 & 53 \\
\hline Others & & 3 & 4 \\
\hline
\end{tabular}

(1) More than one alternative could be chosen.

Among the activities developed for oncology patients, this study identified home visits and nursing appointments as the most frequent, which were also found in an observational study carried out in 27 family health units, distributed in 10 Brazilian states. $^{12}$
Home visits are strengthened as a strategy of care, disease prevention and health promotion, and proved to be care tools for users conditioned to chronic diseases..$^{13}$ In the present study, almost all professionals reported performing them, providing the oncology patients and their family members an evaluation 
with the nurse's special attention. On the other hand, a study conducted in the city of Assis, state of São Paulo, found lower percentages $(78 \%)$ in their execution, and $22 \%$ said they did not perform home visits. ${ }^{14}$

Nursing appointments are an important instrument that brings individuals and families closer to nurses, so all professionals are expected to perform them, although it was the second activity most cited in this study. It contributes to reduce rates of depression, fatigue, sleep disorders, stress, and pain level, ensuring patient's quality of life and well-being. ${ }^{15}$

In addition to performing follow-up activities for the patients, the FHS team should provide assistance to the patients' families. Another study showed that caregivers and relatives of people with terminal illnesses need physical, practical and psychosocial support to face the demands of home care; however, there is reluctance on the part of caregivers and family members to express their own needs. ${ }^{11}$

In this research, more than half of the professionals assisted oncology patients' family members, providing them with guidance on both patient care, and care for their own health, contradicting a study carried out in the city of Botucatu, state of São Paulo, which did not identify any direct care from FHS professionals to patients' caregivers or relatives in palliative care, although it is their role. ${ }^{16}$ Care is focused on the person with cancer, and the needs of caregivers or family members are often neglected by health professionals. ${ }^{11}$ A study carried out in Scotland proposes that primary health care teams be proactive and seek, within their localities, caregivers, as they tend not to identify themselves, and do not ask for help. ${ }^{17}$

The development of a suitable system for palliative care involves the contribution of the interested parts of each nation state together with world support. UK, Belgium and Canada already have excellent pediatric palliative care systems in place. Patients rely on their caregivers to provide adequate guidance, meet their needs, and provide the necessary support until their death. ${ }^{18}$ Palliative care is also part of nurses' care, who should be disseminators of palliative care, even if in a careful and progressive way; this assistance can be developed in different contexts, including the home environment. ${ }^{8}$ Most home palliative care in Ontario/Canada is provided by the public health system that identifies patients in need of such care, coordinates actions, and hires personnel for the provision of services, primarily nursing care. ${ }^{19}$

Despite being a topic that has been discussed since the 1960 s, ${ }^{20} \mathrm{FHS}$ nurses said they did not know what palliative care is, which is disturbing due to the existing fragility of oncology patients and their relatives. This becomes even more serious when the majority of those surveyed stated that they did not provide it, with the main justification that it is not necessary. However, care should start at the time of diagnosis. ${ }^{18}$ Studies show that FHS professionals feel unprepared to perform this kind of home care for patients and families. ${ }^{16}$
Most of the treatment of cancer is characterized as a traumatic process for patients and their families, due to various physiological, physical and psychological changes. ${ }^{21} \mathrm{FHS}$ nurses should be aware of these changes and, therefore, give guidelines that contribute to their patients' quality of life improvement.

Among the main side effects of chemotherapy and radiotherapy treatments are nausea and vomiting, neutropenia, mucositis, xerostomy, skin lesions, fatigue and anxiety. ${ }^{22-24}$ Therefore, it is worrying that only a little more than half of the nurses provide guidelines for better adaptation to treatment.

Providing support, delivering service, and improving the quality of life of oncology patients are priorities in the UK guidelines..$^{25}$ The PNAO establishes guidelines for cancer control in Brazil, from health promotion to palliative care, strengthening strategies of control, and qualifying cancer care. ${ }^{3}$

However, in this study, it is worth mentioning that almost all nurses were unaware of PNAO guidelines, and a minority correctly understood the proposals for oncology care, which may have a negative impact on the quality of care provided to oncology patients.

Among the main difficulties encountered in assisting cancer patients was the lack of training in oncology, also cited in a study carried out in Brazil and Portugal, ${ }^{26}$ in which nursing professionals declared lack of training as a reason for dissatisfaction. A study conducted with Zambian nurses also revealed that the lack of oncology training contributes to negative experiences and prevents the provision of optimal nursing care, a concern that exists in developed and developing countries, ${ }^{27}$ evidencing, again, the need for training primary healthcare professionals for assisting oncology patients. ${ }^{3}$

Regarding facilitating aspects reported by the nurses, care with no emotional appeal for cancer patients predominated, a fact that is not reported by other researchers who revealed that cancer is the disease that leads professionals to most suffering..$^{21}$ Another study carried out in the Isfahan Province, in Iran, with oncology nurses, highlighted the need for intervention programs to relieve stress and prevent these professionals from being fatigued, as they play an important role in the care of cancer patients..$^{28}$ Psychological and emotional disturbances are expected, due to the highly demanding technical care provided, which can lead to a commotion to be experienced by these workers in their routine. ${ }^{29}$

A study conducted in the UK with oncology nurses and community nurses assessed their self-reported skills and demonstrated that community nurses were less confident in recognizing the late symptoms of the disease, and identified a greater need for training, as their role is continuous in monitoring patients with cancer. ${ }^{30}$ Continuing education has been an important instrument for the construction of professional competence, contributing to work organization. ${ }^{31}$

Thus, most nurses proposed, for the improvement of the assistance to cancer patients, training aimed at the PNAO, which 
is of great relevance, as it aims at the qualification, specialization and permanent education of health professionals, who have a critical role in cancer control. ${ }^{3}$

\section{CONCLUSIONS AND IMPLICATIONS FOR PRACTICE}

The care provided by nurses is performed in different ways, in the direct care to both patients and to their families, which shows, mainly, that the professionals inserted in the FHS teams are unprepared to assist patients with cancer in their assigned areas.

Faced with such unpreparedness, the care offered by the primary health care network of the municipality becomes fragile, causing a negative impact on care delivery and on the quality of life of these patients and their families.

Nurses' lack of knowledge about the PNAO is a challenge for managers, because it guides the care of users with cancer, and its wide dissemination within FHS teams is necessary. Investment in these professionals is essential, due to the explicit need for permanent education to qualify them and to ensure an efficient and modifying care to oncology patients and their families.

\section{REFERENCES}

1. Stewart BW, Wild CP. Cancer Worldwide. In: Stewart BW, Wild CP, eds. World Cancer Report 2014. Lyon: International Agency for Research on Cancer; 2014.

2. Ministério da Saúde (BR). Instituto Nacional de Câncer José Alencar Gomes da Silva. Estimativas 2016. Rio de Janeiro: INCA; 2016 [cited 2015 May 4]. Available from: http://www.inca.gov.br/estimativa/2016/ tbregioes_consolidado.asp

3. Ministério da Saúde (BR). Portaria o 2439, de 5 de dezembro de 2005. Institui a Política Nacional de Atenção Oncológica: Promoção, Prevenção, Diagnóstico, Tratamento, Reabilitação e Cuidados Paliativos, a ser implantada em todas as unidades federadas, respeitadas as competências das três esferas de gestão. Brasília (DF): Diário Oficial da União; 2005.

4. Moraes DC, Almeida AM, Figueiredo EN, Loyola EAC, Panobianco MS. Opportunistic screening actions for breast cancer performed by nurses working in primary health care. Rev Esc Enferm USP [Internet]. 2016 Feb; [cited 2017 Mar 3]; 50(1):14-21. Available from: http://www.scielo. br/scielo.php?script=sci_arttext\&pid=S0080-62342016000100014\&lng =en\&nrm=iso. $h$ ttp://dx.doi.org/10.1590/S0080-623420160000100002

5. Fertonani HP, Pires DEP, Biff D, Scherer MDA. The health care model: concepts and challenges for primary health care in Brazil. Ciênc Saúde Coletiva [Internet]. 2015 Jun; [cited 2016 Mar 12]; 20(6):1869-78. Available from: http://www.scielo.br/pdf/csc/v20n6/en_1413-8123csc-20-06-1869.pdf. DOI: 10.1590/1413-81232015206.13272014

6. Costa EMS, Peres AM, Bernardino E, Sade PMC. Leadership styles that act of nurses in health strategy. Cienc Cuid Saude [Internet]. 2015 Jan/Mar; [cited 2016 Apr 14]; 14(1):962-69. Available from: file:///C:/ Users/SESAU/Desktop/20756-113027-1-PB.pdf. DOI: 10.4025/ cienccuidsaude.v14i1.20756

7. Santos TRA, Souza SR. Nursing interventions for children and adolescents with cancer during the chemotherapy treatment. J Res Fundam Care Online [Internet]. $2015 \mathrm{Jul} / \mathrm{Sep}$; [cited $2016 \mathrm{Mar}$ 15]; 7(3):2853-64. Available from: http://www.seer.unirio.br/index. $\mathrm{php} /$ cuidadofundamental/article/view/3813/pdf 1636. http://dx.doi. org/10.9789/2175-5361.2015.v7i3.2853-2864
8. Marchi JA, Paula CC, Girardon-Perlini NMO, Sales CA. The meaning of being-a-caregiver of a dependent relative suffering from cancer: palliative contributions. Texto Contexto-Enferm [Internet]. 2016; [cited 2016 May 23]; 25(1):e0760014. Available from: http://www.scielo.br/pdf/ tce/v25n1/en_0104-0707-tce-25-01-0760014.pdf

9. Marques ALN, Ferreira MBG, Duarte JMG, Costa NS, Haas VJ, Simões ALA. Quality of life and working context of nursing professionals of the family health strategy. Rev Rene [Internet] 2015 Sep/Oct; [cited 2016 Apr 17]; 16(5):672-81. Available from: http://www.revistarene.ufc.br/ revista/index.php/revista/article/view/2058/pdf. DOI: 10.15253/21756783.2015000500008

10. de Almeida Lima C, Marinho LM, Caetite LC, Ribeiro CDAL. Atributos da Atenção Primária: perspectiva e perfil de enfermeiros da estratégia saúde da família. Renome Rev Norte Minas Enferm [Internet]. 2015 [cited 2016 Jan 15]; 4(2):4-18. Available from: http://www.renome unimontes.br/index.php/renome/article/view/90

11. Aoun SM, Deas K, Howting D, Lee G. Exploring the Support Needs of Family Caregivers of Patients with Brain Cancer Using the CSNAT: A Comparative Study with Other Cancer Groups. PLoS One [Internet] 2015 Dec; [cited 2016 Jun 23]; 10(12):e0145106. Available from: http:// journals.plos.org/plosone/article?id=10.1371/journal.pone.0145106 DOI: http://dx.doi.org/10.1371/journal.pone.0145106

12. Bonfim D, Fugulin FMT, Laus AM, Peduzzi M, Gaidzinski RR. Time standards of nursing in the Family Health Strategy: an observational study Rev Esc Enferm USP [Internet]. 2016; [cited 2016 Apr 15]; 50(1):11826. Available from: http://www.scielo.br/pdf/reeusp/v50n1/00806234-reeusp-50-01-0121.pdf. DOI: http://dx.doi.org/10.1590/S0080623420160000100016

13. Silva IS, Arboit EL, Silveira MR, Cavalheiro ITF, Krause KMO, Menezes LP. Visita Domiciliar: Estratégia para a promoção da saúde de pacientes crônicos. Rev Enferm [Internet]. 2016; [cited 2017 Apr 18] 12(12):88-99. Available from: http://www.revistas.fw.uri.br/index.php/ revistadeenfermagem/article/view/2422/2240. ISSN 2317-6075

14. Gomes MFP, Fracolli LA, Machado BC. Atenção domiciliar do enfermeiro na estratégia saúde da família. Mundo Saúde [Internet]. 2015; [cited 2016 Jan 22]; 39(4):470-75. Available from: http://www.saocamilosp.br/pdf/mundo_saude/155572/A08.pdf. DOI: 10.15343/01047809.20153904470475

15. Ramos AF, Fonseca C, Coelho I, Guia S, Santos V. Indicators sensitive to nursing care in people with oncological disease: systematic review of the literature. J Aging Innov [Internet]. 2015 Apr; [cited 2016 Apr 21] 5(1):10-28. Available from: http://www.journalofagingandinnovation.org/ wp-content/uploads/2-Enfemagem-indicadores-oncologia.pdf. ISSN Online: 2182-696X

16. Meneguin S, Ribeiro R. Difficulties of caregivers Providing palliative care to patients covered by the family health strategy. Texto Contexto-Enferm [Internet]. 2016 Mar; [cited 2016 Jun 20];25(1):e3360014. Available from: http://www.scielo.br/pdf/tce/v25n1/en_0104-0707-tce-25-01-3360014. pdf. http://dx.doi.org/10.1590/0104-0707201500003360014

17. Carduff E, Jarvis A, Highet G, Finucane A, Kendall M, Harrison N, et al Piloting a new approach in primary care to identify, assess and support carers of people with terminal illnesses: a feasibility study. BMC Fam Pract. [Internet] 2016 Feb; [cited 2017 Apr 24]; 17(1):18. Available from: https://bmcfampract.biomedcentral.com/articles/10.1186/s12875-0160414-2. DOI: 10.1186/s12875-016-0414-2

18. Ramsey RJM, Matt SB. Policy Review and Recommendations: Palliative Care for Pediatric Patients in the United States of America. J Comm Pub Health Nurs [Internet]. 2016; [cited 2017 May 11]; 2(4):144. Available from: https://www.omicsonline.org/open-access/policy-review-andrecommendations-palliative-care-for-pediatric-patients-inthe-united-statesof-america-2471-9846-1000144.pdf. DOI: 10.4172/2471-9846.1000144

19. Seow H, Brazil K, Sussman J, Pereira J, Marshall D, Austin PC, et al. Impact of community based, specialist palliative care teams on hospitalisations and emergency department visits late in life and hospital deaths: a pooled analysis. BMJ [Internet]. 2014 Jun; [cited 2017 May 5] 348:g3496. Available from: http://www.bmj.com/content/bmj/348/bmj. g3496.full.pdf. https://doi.org/10.1136/bmj.g3496 
20. Pessalacia JDR, Ribeiro IK, Zaboli LCP. Equidade no acesso aos cuidados paliativos na atenção primária à saúde: uma reflexão teórica. Rev Enferm Cent Oeste Min [Internet]. 2016 Jan/Mar; [cited 2016 Jun 12]; 6(1):2119-139. Available from: http://www.seer.ufsj.edu.br/index. php/recom/article/view/1072/1017. http://dx.doi.org/10.19175/recom. voi0.1072

21. Menegócio AM, Rodrigues L, Teixeira GL. Enfermagem Oncologia: relação de afetividade ou meramente técnica? Ensaios Ciênc Biol Agrar Saúde [Internet]. 2015; [cited 2016 Aug 27]; 19(3):118-23. Available from: http://www.redalyc.org/pdf/260/26042169004.pdf. http://dx.doi. org/10.17921/1415-6938.2015v19n3p\%25p

22. Primo CC, Cesar FD, Lima EFA, Caniçali RA, Leite FMC. Nursing care to patients with head and neck cancer undergoing radiotherapy. J Res Fundam Care Online [Internet] 2016 Jan/Mar; [cited 2016 Jun 14]; 8(1):3820-31. Available from: http://www.seer.unirio.br/index.php/ cuidadofundamental/article/view/4173/pdf_1795. DOI: 10.9789/21755361.2016.v8i1.3820-3831

23. Carlucci VDS, Bragaz FTMM, Reis PED, Silveira RCCP. Sing care provided to hematologic cancer patients receiving high-dose chemotherapy: an integrative review. Rev Enferm UFPE On Line [Internet]. 2016 Apr; [cited 2016 Jul 10]; 10(Supl.3):1544-55. Available from: http://www.revista.ufpe.br/revistaenfermagem/index.php/revista/ article/view/7581/pdf_10106. DOI: 10.5205/reuol.7057-60979-3-SM1.1003 sup20162

24. Andrade M, Clapis MJ, Santos CB, Gozzo TO. Development of an instrument to identify nurses' practice in radiodermatitis. Uerj Nurs J [Internet]. 2015 Nov/Dec; [cited 2016 Jul 12]; 23(6):74753. Available from: http://www.e-publicacoes.uerj.br/index.php/ enfermagemuerj/article/view/12677/16136. http://dx.doi.org/10.12957/ reuerj.2015.12677

25. Corner J, Wangland R, Glaser A, Richards SM. Qualitative analysis of patients' feedback from a PROMs survey of cancer patients in England. BMJ Open [Internet]. 2013; [cited 2017 May 30]; 3:e002316. Available from: http://bmjopen.bmj.com/content/bmjopen/3/4/e002316.full.pdf. DOI: 10.1136/bmjopen-2012-002316
26. Bordignon M, Monteiro MI, Mai S, Martins MFSV, Rech CRA, Trindade LL. Oncolgy nursing professionals job satisfaction and dissatisfaction in Brazil and Portugal. Texto Contexto-Enferm [Internet]. 2015 Oct/Dec; [cited 2016 Jul 17]; 24(4):925-33. Available from: http://www.scielo.br/ pdf/tce/v24n4/0104-0707-tce-201500004650014.pdf. http://dx.doi. org/10.1590/0104-0707201500004650014

27. Maree JE, Mulonda JK. Caring for Patients with Advanced Breast Cancer: The Experiences of Zambian Nurses. Asia Pac J Oncol Nurs [Internet]. 2017 Jan/Mar; [cited 2017 Jul 19]; 4(1):23-28. Available from:https://www.ncbi.nlm.nih.gov/pubmed/?term=PMC5297227.DOI: 10.4103/2347-5625.199077

28. Taleghani F, Ashouri E, Saburi M. Empathy, Burnout, Demographic Variables and their Relationships in Oncology Nurses. Iran J Nurs Midwifery Res [Internet]. $2017 \mathrm{Jan} / \mathrm{Feb}$; [cited 2017 Apr 23]; 22(1):4145. Available from: https://www.ncbi.nlm.nih.gov/pubmed/28382057. DOI: 10.4103/ijnmr.IJNMR_66_16

29. Salimena AMO, Teixeira SR, Amorim TV, Paiva ACPC, Melo MCSC. O vivido dos enfermeiros no cuidado ao paciente oncológico. Cogitare Enferm [Internet]. 2013 Jan/Mar; [cited 2016 Nov 30]; 18(1):142-7. Available from: http://revistas.ufpr.br/cogitare/article/view/31320/20027. http://dx.doi.org/10.5380/ce.v18i1.31320

30. Faithfull S, Samuel C, Lemanska A, Warnock C, Greenfield D. Selfreported competence in long term care provision for adult cancer survivors: A cross sectional survey of nursing and allied health care professionals. Int J Nurs Stud [Internet] 2016 Jan; [cited 2017 May 9]; 3:85-94. Available from: http://www.journalofnursingstudies.com/ article/S0020-7489(15)00264-3/pdf. http://dx.doi.org/10.1016/j. ijnurstu.2015.09.001

31. Puggina CC, Amestoy SC, Fernandes HN, Carvalho LA, Báo ACP, Alves FO. Educação permanente em saúde: instrumento de transformação do trabalho de enfermeiros. Rev Esp Saúde [Internet]. 2015 Oct/Dec; [cited 2017 Mar 4]; 16(4):87-97. Available from: http://www.uel.br/ revistas/uel/index.php/espacoparasaude/article/view/22580. http:// dx.doi.org/10.22421/1517-7130.2015v16n4p87 